\title{
Az akut pancreatitist követő kórházi visszavételi arány mint minőségi mutató
}

\author{
Illés Dóra dr. - Czakó László dr. \\ Szegedi Tudományegyetem, Általános Orvostudományi Kar, Belgyógyászati Klinika, Szeged
}

\begin{abstract}
Bevezetés: Az akut pancreatitis az egyik leggyakoribb kórházi felvételt igénylő gastrointestinalis kórkép. A korai viszszavételi arány egyrészt az ellátást jellemzó minőségi mutató, másrészt az akut pancreatitis 1 éves mortalitásának legerősebb prognosztikai faktora.

Célkitüzés: A korai visszavétel arányának, illetve okainak vizsgálata klinikánkon akut pancreatitis diagnózisával kezelt betegek körében.

Módszerek: Retrospektív vizsgálatunkat azon 18 év feletti betegek körében végeztük, akiket a 2010. január és 2018. december közötti időszakban akut pancreatitis diagnózisával kezeltünk klinikánkon, és az első emissziótól számítva 30 napon belül újból felvételre kerültek. A betegek adatait az Akut Pancreatitis Regiszter és a betegnyilvántartó rendszer (MedSol ) segítségével gyúijtöttük össze. A biliaris, illetve nem biliaris akut pancreatitises eseteket hasonlítottuk össze az epidemiológiai adatok, a visszavétel oka, a visszavételig eltelt átlagos idôtartam, és a visszavétel időtartama, valamint kimenetele vonatkozásában.

Eredmények: Akut pancreatitis diagnózisával 647 beteg került felvételre. Közülük 28 beteg került újrafelvételre. A leggyakoribb okok között 1) peripancreaticus szövődmények, 2) epés panaszok és 3) az akut pancreatitis kiújulása szerepel. A biliaris és a nem biliaris pancreatitises eseteket összehasonlítva, a visszavétel oka epés panasz volt az előbbi csoport 65,5\%-ában és az utóbbi 15\%-ában. A középsúlyos pancreatitises esetek száma szignifikánsan magasabbnak adódott a nem biliaris csoportban.

Köpetkeztetés: A középsúlyos/súlyos pancreatitises esetek aránya magasabb volt a nem biliaris pancreatitises csoportban. Biliaris pancreatitis esetén javasolt index-cholecystectomia végzése.
\end{abstract}

Orv Hetil. 2021; 162(11): 413-418.

Kulcsszavak: akut pancreatitis, 30 napos visszavételi arány, cholecystectomia

\section{Rate of early hospital readmission in acute pancreatitis as a quality marker}

Introduction: Acute pancreatitis is the leading cause of hospitalization among gastrointestinal diseases. The early readmission rate is a quality marker and the strongest prognostical factor of 1 -year mortality of acute pancreatitis. Objective: To investigate the rate and cause of early readmission among patients treated with acute pancreatitis at our clinic.

Methods: Our retrospective study was conducted among patients ( $>18$ years) treated with acute pancreatitis between January 2010 and December 2018 at our clinic, by whom unplanned readmission happened <30 days from emission. Personal data were collected from the Hungarian Pancreas Registry. Data of biliary and non-biliary acute pancreatitis cases were compared concerning epidemiological data, cause of readmission, mean time elapsed until readmission, its duration and outcome.

Results: 647 patients were diagnosed with acute pancreatitis. Of them, 28 patients had early readmission. The most common causes were 1) local pancreatic complications, 2) biliary and 3) recurrence of acute pancreatitis. By investigating the biliary and non-biliary pancreatitis cases separately, the cause of readmission was biliary in $65.5 \%$ and $15 \%$, respectively. The number of moderately severe pancreatitis cases was significantly higher in the non-biliary group. Conclusion: The proportion of moderate/severe diseases was higher in the non-biliary pancreatitis group. In the case of biliary pancreatitis, it is suggested to perform index cholecystectomy.

Keywords: acute pancreatitis, 30-day readmission, cholecystectomy

Illés D, Czakó L. [Rate of early hospital readmission in acute pancreatitis as a quality marker]. Orv Hetil. 2021; 162(11): 413-418.

(Beérkezett: 2020. augusztus 26.; elfogadva: 2020. szeptember 24.) 


\section{Rövidítések}

AGA $=$ (American Gastroenterological Association $)$ Amerikai Gasztroenterológiai Szövetség; APA = (American Pancreatic Association) Amerikai Hasnyálmirigy Szövetség; ERCP = endoszkópos retrográd cholangiopancreatographia; IAP $=(\mathrm{In}-$ ternational Association of Pancreatology) Nemzetközi Pankreatológiai Szövetség; STROBE = (Strengthening the Reporting of Observational Studies in Epidemiology) kezdeményezés az epidemiológiai megfigyeléses vizsgálatok eredményközlésének javításáért; SZTE = Szegedi Tudományegyetem

Az akut pancreatitis a gastrointestinalis betegségek között vezető oka a kórházi felvételnek. 2012-ben az Amerikai Egyesült Államokban 274000 beteg került akut pancreatitis diagnózisával kórházi felvételre [1]; a betegség incidenciája folyamatos emelkedést mutat [2]. Súlyos akut pancreatitis esetén a mortalitási ráta a $30-50 \%$-ot is eléri [3]. Egy prospektív magyar kohorsztanulmány szerint a halálozási ráta 28,3\%-nak adódott súlyos akut pancreatitis esetén szemben a középsúlyos $(0,6 \%)$, illetve enyhe $(0,3 \%)$ akut pancreatitises esetekkel - ez utóbbi két csoport halálozási rátája között nem adódott szignifikáns különbség. A kórházi kezelés költsége (csupán a gyógyszerek, a vizsgálatok és a beavatkozások költségével számolva) enyhe akut pancreatitis esetén 99006 forint volt; ez azonban 1725135 forintra emelkedett súlyos akut pancreatitis esetén [4]. Az akut pancreatitis miatti kórházi kezelés költsége megközelítőleg 2,6 milliárd dollár évente [1]. Ezen adatok tükrében nyilvánvaló, hogy önmagában az első akut pancreatitises epizód miatti felvétel is jelentős kórházi költséget képez, mely csak tovább gyarapszik abban az esetben, ha a beteg újrafelvételre kerül. Definíció szerint újrafelvételen a beteg meghatározott időintervallumon belüli, ismételt hospitalizációját értjük az első felvétel diagnózisával egyező okból [5]. Általánosságban véve a visszavétel nemcsak az eredeti betegség visszatérése vagy a beteg korai hazabocsátása következtében történhet meg, hanem az első felvétel során végzett kezelés késői mellékhatásainak következménye is lehet. Ez alapján a visszavétel a kórházi ellátás minőségi mutatójaként szerepel. A korai (az első felvétel végeztével történt hazabocsátástól számított 30 napon belüli) visszavétel általában arra utal, hogy a primer hospitalizáció és a visszavétel között ok-okozati kapcsolat van, ennek megfelelően a két eset finanszírozásilag is kapcsolttá válik, anyagi deficitet okozva [5]. Emiatt a korai visszavétel arányának csökkentése a költséghatékonyságot segíti elő. Ezzel párhuzamosan Lee és mtsai bebizonyították, hogy a nem tervezett korai visszavétel az akut pancreatitis 1 éves mortalitásának legerősebb prediktora [6]. A korai visszavételnek a fentiekben szemléltetett fontossága ellenére kevés adat áll rendelkezésre a témával kapcsolatosan az irodalomban. Ezekben az akut pancreatitis első kezelését követő visszavétel aránya 15$29 \%$ között változik [5-11]. A visszavétel leggyakoribb okai között az akut pancreatitis visszatérése; fellángoló panaszok, úgymint hányinger, hányás és hasi fájdalom
[6]; az akut pancreatitis késői lokális szövődményei (pseudocysta, demarkált pancreasnecrosis és epeúti abnormalitások) szerepelnek [11]. A jelen kutatás során célunk az akut pancreatitis diagnózisa miatt klinikánkon primeren kezelt betegek 30 napos, nem tervezett visszavételi arányának, a visszavétel okának és kimenetelének vizsgálata volt.

\section{Módszerek}

\section{Kutatási terv és betegek}

Az akut pancreatitis diagnózisával 2010. január 1. és 2018. december 31. között kezelt, 18 év feletti betegek személyes adatait az Akut Pancreatitis Regiszter segítségével gyújtöttük össze, írásos beleegyezést követően. A vizsgálatba azon betegeket vontuk be, akik az első akutpancreatitis-ellátást követóen 30 napon belül nem tervezetten kórházi újrafelvételre kerültek. Kizártuk azokat az eseteket, amelyekben a visszavétel tervezett volt, illetve amikor a betegek folyamatos kórházi kezelés következtében másik egységből kerültek átvételre. Azon betegek, akiknél az utánkövetés nem volt kivitelezhető, szintén kizárásra kerülttek. Az epidemiológiai adatok mellett az akut pancreatitis etiológiája és súlyossága, az első felvételt követő kórházi benntartózkodás hossza, a visszavételig eltelt idő, a visszavétel oka, időtartama és kimenetele került feldolgozásra. A biliaris és nem biliaris akut pancreatitises betegek között a fenti paraméterek vonatkozásában alcsoport-analízist végeztünk. Az akut pancreatitis súlyosságát a módosított Atlanta-klasszifikáció alapján állapítottuk meg [12].

\section{Etikai engedély}

A kutatást a Szegedi Tudományegyetem Általános Orvostudományi Karának regionális Humán Orvosbiológiai Kutatásetikai Bizottsága engedélyezte (140/ 2019-SZTE), és összhangban áll a Helsinki Deklaráció által elő́rtakkal. Kohorszvizsgálatunk a STROBE szakmai protokollt követi [13].

\section{Statisztikai analizis}

A diszkrét változókat átlag és standard deviáció segítségével fejeztük ki, a köztük levő eltérés vizsgálatára kétmintás t-próbát alkalmaztunk. A 0,05 alatti p-értéket tekintettük statisztikailag szignifikánsnak.

\section{Eredmények}

Az adott időintervallumban 647 beteg került akut pancreatitis diagnózisával felvételre klinikánkra az Akut Pancreatitis Regiszter alapján. Az utánkövetéshez szükséges információk hiányában 119 beteget zártunk ki. 28 beteg került korai visszavételre $(5,3 \%), 42,8 \%$ nő, átlagéletkor 


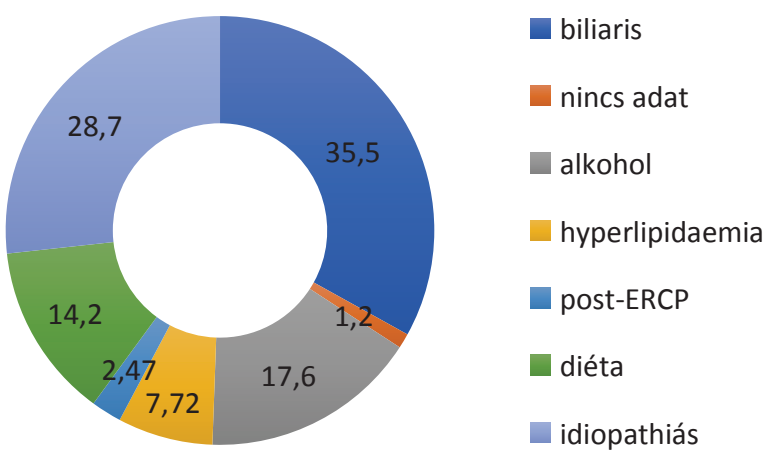

1. ábra $\quad$ Az első akut pancreatitises epizód vezető etiológiai faktorainak aránya (\%)

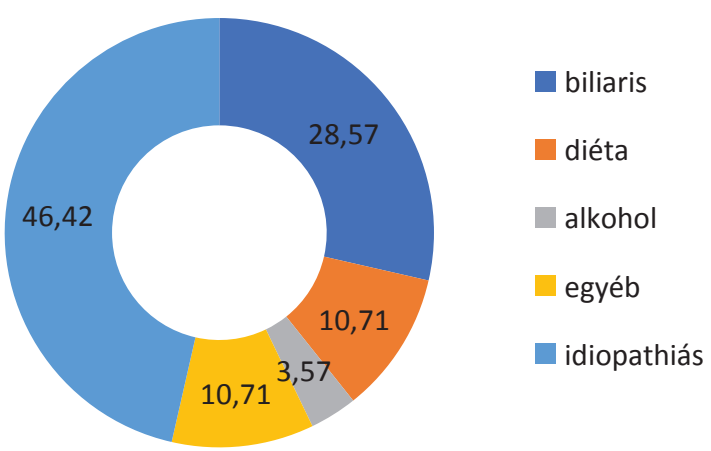

2. ábra $\quad$ Az első akut pancreatitis etiológiai faktorai a visszavételre került betegek körében (\%)

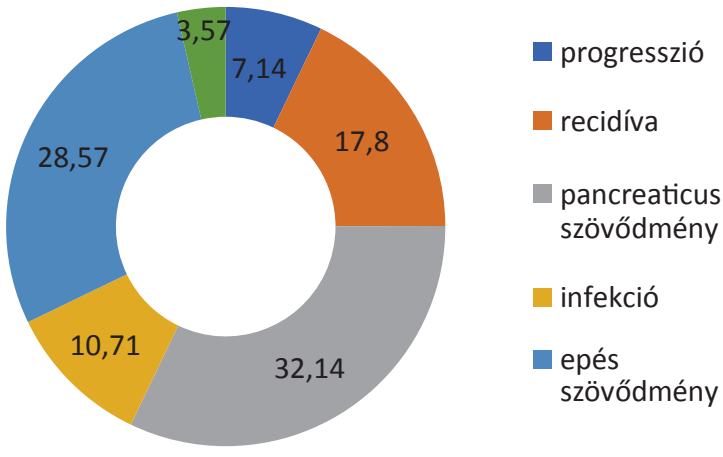

3. ábra $\quad$ A leggyakoribb visszavételi okok (\%)

$57,7 \pm 13$ év. Az 528 beteg közül 187 (35,4\%) biliaris, míg $341(64,6 \%)$ nem biliaris akut pancreatitis miatt került felvételre. A biliaris akut pancreatitises csoport 4,3\%-a, míg a nem biliaris akut pancreatitises csoport $5,8 \%$-a került újrafelvételre, mely arány szignifikáns eltérést nem mutat $(\mathrm{p}=0,332)$. Mind a 28 beteg csak egy alkalommal került korai újrafelvételre. Az 1. ábra a primer akut pancreatitises epizód fó etiológiai faktorait mutatja be. Az esetek 28,5\%-ában specifikus ok nem volt kimutatható (idiopathiás akut pancreatitis), ezen eseteket a nem biliaris akut pancreatitises esetek közé soroltuk. A visszavételre került betegek között a nem biliaris primer akut pancreatitises esetek aránya magasabb volt, mint a biliaris akut pancreatitises eseteké $(71,43 \%$ vs. $28,57 \%, 2$ ábra). A visszavétel 3 leggyakoribb oka a következő volt: a pancreatitis helyi komplikációi (pseudocysta, demarkált pancreasnecrosis, necrosis), epeúti infekció (cholecystitis, cholangitis) és relabáló akut pancreatitis (3. ábra). Az epeúti infekciók mint visszavételi ok aránya szignifikánsan magasabbnak adódott a biliaris akut pancreatitises csoportban, összehasonlítva a nem biliaris akut pancreatitises csoporttal $(\mathrm{p}=0,042)$ (1. táblázat). Az újrafelvétel 4. leggyakoribb oka a nem epeúti infekció volt (10,7\%), a legyakrabban Clostridium difficile fertőzés. A primer ellátás és a visszavétel alatti kórházi benntartózkodás hosszát, valamint a kettő között eltelt időt a 2. táblázat mutatja. Bár ezen időtartamok hosszában statisztikailag szignifikáns különbség nem volt kimutatható, egyértelmű tendencia ismerhető fel: a két felvétel között eltelt idő rövidebb, az újrafelvétel miatti kórházi benntartózkodás hosszabb volt a nem biliaris akut pancreatitises csoportban. 14 esetben (50\%) a primer akut pancreatitis enyhe lefolyású volt (1. táblázat). A középsúlyos akut pancreatitises esetek aránya szignifikánsan magasabb volt a nem biliaris akut pancreatitises csoportban ( 11 vs. $2 ; \mathrm{p}=0,048$ ). A visszavétel során egy esetben sem történt intenzív osztályos ellátás, illetve halálozás nem volt. A biliaris akut pancreatitises

1. táblázat A visszavétel legfóbb etiológiai faktorai és a kezdeti akut pancreatitis súlyossága a biliaris és a nem biliaris csoportban

\begin{tabular}{lcc}
\hline Ok & $\begin{array}{c}\text { Biliaris csoport, } \\
\mathrm{n}(\%)\end{array}$ & $\begin{array}{c}\text { Nem biliaris csoport, } \\
\mathrm{n}(\%)\end{array}$ \\
\hline Progresszió & $0(0)$ & $2(10)$ \\
Relapsus & $0(0)$ & $5(25)$ \\
Pancreaticus & $2(25)$ & $7(35)$ \\
Infekció & $0(0)$ & $3(15)$ \\
Biliaris & $5(62,5)$ & $3(15)$ \\
Egyéb & $1(12,5)$ & $0(0)$ \\
\hline Súlyosság & & $8(40)$ \\
\hline Enyhe & $6(75)$ & $11(55)^{*}$ \\
Középsúlyos & $2(25)$ & $1(5)$ \\
Súlyos & $0(0)$ &
\end{tabular}

*Szignifikáns különbség: $\mathrm{p}=0,042(\mathrm{p}<0,005)$

2. táblázat |Az első és a második bennfekvés időtartama és a kettő között eltelt idő

\begin{tabular}{lcccc}
\hline Időtartam & Átlag (nap) & $\begin{array}{c}\text { Biliaris csoport } \\
\text { (nap) }\end{array}$ & $\begin{array}{c}\text { Nem biliaris } \\
\text { csoport (nap) }\end{array}$ & $\mathrm{p}$ \\
\hline $\begin{array}{l}\text { 1. kórházi } \\
\text { bennfekvés }\end{array}$ & $12,6 \pm 9,11$ & $9,75 \pm 8,65$ & $14,05 \pm 9,22$ & 0,14 \\
$\begin{array}{l}2 . \text { kórházi } \\
\text { bennfekvés }\end{array}$ & $11,6 \pm 10,1$ & $9,87 \pm 5,15$ & $12,35 \pm 11,5$ & 0,23 \\
$\begin{array}{l}\text { A visszavételig } \\
\text { eltelt idő }\end{array}$ & $13,5 \pm 8$ & $13,87 \pm 7,39$ & $8 \pm 0$ & 0,44 \\
\hline
\end{tabular}


csoportban 7 beteg $(87,5 \%)$ esett át endoszkópos retrográd cholangiopancreatographián (ERCP) a primer felvétel során. Egy esetben sem került sor cholecystectomiára az első kórházi felvétel alatt. l esetben terhesség miatt endoszkópos ultrahangvizsgálatra került sor, mely ERCP-indikációt nem támogatott. A beteg késóbb cholecystitis miatt került újrafelvételre. ERCP-vizsgálatot követően 3 esetben $(42,8 \%)$ cholecystitis, l esetben $(14,2 \%)$ cholangitis miatt került a beteg újrafelvételre. A lokális pancreatogen szövődmények aránya a következőképpen alakult: demarkált pancreasnecrosis 5 esetben, pseudocysta 3 esetben alakult ki, döntően (75\%) a nem biliaris csoportban. Sebészi beavatkozásra 4 esetben volt szükség. A 12 hónapos követési idő alatt a 28, visszavételre került beteg közül 3 hunyt el, ami alapján az l éves mortalitási ráta $10,7 \%$-nak adódott.

\section{Megbeszélés}

A jelen kutatás során a klinikánkon akut pancreatitis diagnózisával kezelt betegek körében vizsgáltuk a korai, nem tervezett visszavételi arányt. Bár a korai visszavételi ráta a kórházi ellátás minőségi mutatója, csupán pár publikáció jelent meg ebben a témában $[5,7,8,10,11,14]$. A visszavétel elkerülhető okainak ismerete a visszavételi arány csökkenéséhez, ezen keresztül jobb és költséghatékonyabb ellátáshoz vezet.

Kutatásunk során a visszavételi arány 5,3\%-nak adódott, mely a nemzetközi adatokhoz viszonyítva kiemelkedően alacsony [5-11]. Ennek magyarázata egyrészről a kutatás korlátjában keresendő: 119 beteg esetén nem állt rendelkezésre elég információ az utánkövetéshez hármas progresszivitási szintû intézményként más egészségügyi intézmények betegnyilvántartó rendszeréhez az információbiztonsági irányelvek miatt nincs hozzáférésünk. Másrészről, következhet a kutatási protokoll felépítéséból: a folyamatos ellátás keretében más osztályról (például intenzív osztályról) átvett betegek kizárásra kerültek. Definíció szerint az akut pancreatitis súlyos, ha 48 órát meghaladó egy- vagy többszervi elégtelenség áll fenn [12], mely intenzív osztályos kezelést tesz indokolttá, akár az akut pancreatitis korai szakaszában. A halálo-

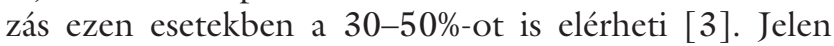
vizsgálatunk alátámasztja a fenti tendenciát: csupán a visszavételre került betegek 3,5\%-a (1 beteg) esett át súlyos akut pancreatitises primer epizódon. Mi több, néhány, magasabb visszavételi rátát publikáló kutatás kifejezetten súlyos akut pancreatitises esetek körében vizsgálta a visszavételt, mely csoport egyértelmúen nagyobb rizikóval rendelkezik az újrafelvételt illetően [7]. Az idiopathiás akut pancreatitis aránya magasabb/egyenlő a nemzetközi irodalomban publikáltakhoz viszonyítva $(28,7 \%$ vs. $13 \%$ [ 7 ] és $28,7 \%$ vs. $27,3 \%$ [ 5$]$ ]). Ez a jövőben a potenciális etiológiai faktorok alaposabb, részletesebb dokumentálására késztet minket. Az idiopathiás etiológiával kapcsolatban egy dolgot fontos még kiemelni: kutatásunk során a visszavételre kerülő betegek közel 50\%-a primeren idiopathiás akut hasnyálmirigy-gyulladással lett diagnosztizálva. Munigala és mtsai megállapították, hogy az idiopathiás akut pancreatitis magasabb rizikót jelent a korai visszavételre vonatkozóan [11].

A visszavételig eltelt idő és a második felvétel időtartama tendenciózusan rövidebb, illetve hosszabb a nem biliaris akut pancreatitises csoportban, összevetve a biliaris csoporttal. Emellett a nem biliaris csoportban a középsúlyos akut pancreatitis aránya szignifikánsan magasabbnak adódott. Ezen eredmények összhangban vannak az irodalmi adatokkal: Munigala és mtsai azt találták, hogy a nem biliaris etiológia a visszavételre vonatkoztatva magasabb rizikóval bír [11]. A biliaris szövődmények miatti visszavétel aránya szignifikánsan magasabbnak adódott a biliaris akut pancreatitises csoportban, a szövődmény döntően cholecystitis volt. Ezek alapján az index-cholecystectomia (vagyis az akut pancreatitis miatti első kórházi ellátás keretében végzett epehólyag-eltávolítás) elvégzése enyhe biliaris akut pancreatitises esetekben ajánlott lenne, így a biliaris okok miatti visszavételi arány és az összesített kezelési költség is csökkenne: Juo és mtsai egy retrospektív kohorszvizsgálat során megállapították a kumulatív kórházi költségben adódó különbséget terhes nők esetén rutin cholecystectomia és konzervatív kezelés során. Azon betegek, akiknél nem történt index-cholecystectomia, a 30 napos visszavételi arány szignifikánsan magasabbnak adódott $(33,7 \%$ vs. $5,3 \%, \mathrm{p}<0,01)$, a betegek 24,5\%-a intervallum-cholecystectomián (a konzervatívan kezelt betegek esetében az elektív epehólyag-eltávolításig javasolt 4-6 héten belül - túl korán - vált esedékessé az epehólyag eltávolítása) esett át. Bár a primer ellátás költsége magasabb volt az index-cholecystectomián átesett betegek esetében, a kumulatív kórházi ráfordítás összege csökkent, ha a késóbbi újrafelvételeket is figyelembe vették [15]. Da Costa és mtsai egy nemzetközi, randomizált kontrollált vizsgálat során megállapították, hogy az enyhe biliaris akut pancreatitis, illetve az e miatti kórházi felvétel során elvégzett cholecystectomia hatékonyabb és kevésbé költséges volt, mint az 'afroid' szakaszban végzett epehólyag-eltávolítás: az index-cholecystectomia a visszatérő, epekő indukálta szövődmények előfordulásának rizikóját 16,9\%-ról 4,7\%-ra csökkentette akut pancreatitis esetén $(\mathrm{p}=0,002)$ [16]. Mind az AGA, mind az IAP/APA útmutatói javasolják enyhe biliaris akut pancreatitis esetén az index-cholecystectomia elvégzését $[17,18]$. Index-cholecystectomia jelen vizsgálatunk alapján egy esetben sem történt, ami megmagyarázza a biliaris okok miatti visszavételt. Biliaris akut pancreatitis esetén az ERCP jótékony hatású terápiás beavatkozás megfelelő erôs indikáció (például cholangitis) esetén. A terápiás ERCP-t követő szövődmények 7-10\%-ban fordulnak elő [19], emiatt - amennyiben egyértelmú, cholangitist támogató bizonyíték nem áll fenn - az amerikai protokoll alapján endoszkópos ultrahangvizsgálat, illetve mágneses rezonanciás cholangiopancretographia elvégzése indokolt biliaris akut pancreatitis esetén, ERCP elvégzése előtt [20]. Így az esetlegesen 
szükségtelen ERCP-vizsgálat jelentette költségek és szövődményráta csökkenthető.

A visszavételre kerülő betegek 10,7\%-ánál a visszavétel oka a nem biliaris infekció volt, döntően $C$. difficile által. Az akut pancreatitis alapvetóen egy steril gyulladás, mely leukocytosist és a szérum-C-reaktív protein emelkedését okozza az akutfázis-reakció részeként. A legtöbb esetben ezen eltérések miatt antibiotikumkezelést indítanak, fertőzésre utaló jel klinikai hiányában is. Ez az antibiotikumkezelésből fakadó szövődmények ( $C$. difficile infekció, pseudomembranosus colitis, a vékonybél bakteriális egyensúlyának felborulása, fokozott antibiotikumrezisztencia) rizikójának emelkedéséhez vezet. Párniczky és mtsai szisztematikus analízisük során bebizonyították, hogy sem a leukocytosis, sem a C-reaktív protein emelkedése, illetve a láz nem utal infekcióra az akut pancreatitis korai szakaszában. Az infekció kimutatásának hatékonyabb markere a prokalcitonin [21]. Antibiotikumkezelés indítása csak prokalcitoninpozitivitás esetén indokolt az akut pancreatitis korai szakaszában.

Az 1 éves mortalitási ráta a korai, nem tervezett újrafelvételre kerülő betegek között 10,7\%-nak adódott vizsgálatunk során, ami összhangban áll a nemzetközi adatokkal (10\%) [6]. Lee és mtsai retrospektív kutatásuk során azt találták, hogy a magasabb Charlson komorbiditási index és a hosszabb kórházi tartózkodás magasabb rizikót jelent a mortalitásra vonatkozóan [6]. Ez a megállapítás az általunk megfigyelt eredményekkel összeegyeztethető: a 3 elhunyt beteg közül 2 középsúlyos akut pancreatitises epizódon esett át, jelentősen hoszszabb kezdeti bennfekvési időtartammal (29 és 18 nap vs. 12,6 nap); a harmadik beteg hasnyálmirigyrákkal küzdött, emellett enyhe akut pancreatitises epizódon esett át.

\section{Következtetés}

A korai visszavételi arány klinikánkon alacsony a nemzetközi adatokhoz viszonyítva, ami az ellátás minőségét pozitívan jellemzi, azonban a korábban felsorolt limitációk tükrében értékelendő.

$\mathrm{Az}$ akut pancreatitis etiológiájának pontos felderítése javasolt a visszavételi arány csökkentése érdekében: mivel kutatásunk során az idiopathiás akut pancreatitis aránya - a nemzetközi adatoknak nagyrészt megfeleltethetően magasnak igazolódott, potenciálisan reverzibilis/elhárítható okok nem kerültek felderítésre, ez pedig a visszavétel rizikóját emelheti. Ez az anamnézis részletes és pontos felvételével, gyanú esetén a véralkohol-, emellett a vérzsírszintek, a kalciumion, a hemoglobin Alc szintjének rutinszerú meghatározásával nagymértékben csökkenthetô lenne. Nem egyértelmú biliaris etiológia esetén a képalkotó eljárás: endoszkópos ultrahangvizsgálat vagy mágneses rezonanciás cholangiopancreatographia végzése javasolt. A korai, nem tervezett visszavétel és a középsúlyos/súlyos akut pancreatitis aránya magasabb a nem biliaris akut pancreatitises csoportban, így ezen ese- tekben az etiológia pontos tisztázása és az emisszió idejének meghatározása még nagyobb körültekintést igényel. Enyhe biliaris akut pancreatitis esetén javasolt az index-cholecystectomia elvégzése még az első kórházi felvétel során, ezzel párhuzamosan a fekvőbeteg-ellátás finanszírozását meghatározó, jelenleg érvényben lévő Homogén Betegségcsoportok revíziójának megfontolása javasolt. Akut pancreatitis esetén antibiotikumkezelés indítása csak bizonyított fertőzés esetén javasolt, a nem megfelelő antibiotikumkezelésbőll származó szövődmények előfordulásának csökkentése végett.

Anyagi támogatás: A közlemény megírása anyagi támogatásban nem részesült.

Szerzői munkamegosztás: C. L.: A kutatási téma felvetője, a tervezet szellemi szerzője, szakmai véleményezés. I. D.: Adatgyújtés, irodalomkutatás és feldolgozás, a statisztika elkészítése, a kézirat megírása. A cikk végleges változatát mindkét szerző elolvasta és jóváhagyta.

Érdekeltségek: A szerzőknek nincsenek érdekeltségeik.

\section{Irodalom}

[1] Peery AF, Dellon ES, Lund J, et al. Burden of gastrointestinal disease in the United States: 2012 update. Gastroenterology 2012; 143: 1179-1187.e3.

[2] Brindise E, Elkhatib I, Kuruvilla A, et al. Temporal trends in incidence and outcomes of acute pancreatitis in hospitalized patients in the United States from 2002 to 2013. Pancreas 2019; 48: 169-175.

[3] Maléth J, Hegyi P. $\mathrm{Ca}^{2+}$ toxicity and mitochondrial damage in acute pancreatitis: translational overview. Philos Trans R Soc Lond B Biol Sci. 2016; 371: 20150425.

[4] Párniczky A, Kui B, Szentesi A, et al. Prospective, multicentre, nationwide clinical data from 600 cases of acute pancreatitis. PLoS ONE 2016; 11: 0165309.

[5] Suchsland T, Aghdassi A, Kühn K, et al. Predictive factors for and incidence of hospital readmissions of patients with acute and chronic pancreatitis. Pancreatology 2015; 15: 265-270.

[6] Lee PJ, Bhatt A, Lopez R, et al. Thirty-day readmission predicts 1 -year mortality in acute pancreatitis. Pancreas 2016; 45: 561564.

[7] Vipperla K, Papachristou GI, Easler J, et al. Risk of and factors associated with readmission after a sentinel attack of acute pancreatitis. Clin Gastroenterol Hepatol. 2014; 12: 1911-1919.

[8] Yadav D, Lee E, Papachristou GI, et al. A population-based evaluation of readmissions after first hospitalization for acute pancreatitis. Pancreas 2014; 43: 630-637.

[9] Yadav D, O'Connell M, Papachristou GI. Natural history following the first attack of acute pancreatitis. Am J Gastroenterol. 2012; 107: 1096-1103.

[10] Whitlock TL, Repas K, Tignor A, et al. Early readmission in acute pancreatitis: incidence and risk factors. Am J Gastroenterol. 2010; 105: 2492-2497.

[11] Munigala S, Subramaniam D, Subramaniam DP, et al. Predictors for early readmission in acute pancreatitis (AP) in the United States (US). A nationwide population based study. Pancreatology 2017; 17: 534-542.

[12] Banks PA, Bollen TL, Dervenis C, et al. Classification of acute pancreatitis - 2012: revision of the Atlanta classification and definitions by international consensus. Gut 2013; 62: 102-111. 
[13] von Elm E, Altman DG, Egger M, et al. Strengthening the Reporting of Observational Studies in Epidemiology (STROBE) statement: guidelines for reporting observational studies. BMJ 2007; 335: 806-808.

[14] Garg SK, Campbell JP, Anugwom C, et al. Incidence and predictors of readmissions in acute pancreatitis. A nationwide analysis. Pancreas 2018; 47: 46-54.

[15] Juo YY, Khrucharoen U, Sanaiha Y, et al. Cumulative financial burden of readmissions for biliary pancreatitis in pregnant women. Obstet Gynecol. 2018; 132: 415-422.

[16] Da Costa DW, Dijksman LM, Bouwense SA. Cost-effectiveness of same-admission versus interval cholecystectomy after mild gallstone pancreatitis in the PONCHO trial. Br J Surg. 2016; 103: 1695-1703.

[17] Crockett SD, Wani S, Gardner TB, et al. American Gastroenterological Association Institute guideline on initial management of acute pancreatitis. Gastroenterology 2018; 154: 1096-1101

[18] Working Group IAP/APA Acute Pancreatitis Guidelines. IAP/ APA evidence-based guidelines for the management of acute pancreatitis. Pancreatology 2013; 13(4 Suppl 2): el-el5.
[19] Anderloni A, Repici A. Role and timing of endoscopy in acute biliary pancreatitis. World J Gastroenterol. 2015; 21: 1120511208 .

[20] ASGE Standards of Practice Committee, Maple JT, Ben-Menachem T, Anderson MA, et al. The role of endoscopy in the evaluation of suspected choledocholithiasis. Gastrointest Endosc. 2010; 71: 1-9.

[21] Párniczky A, Lantos T, Tóth EM, et al., The Hungarian Pancreatic Study Group. Antibiotic therapy in acute pancreatitis: from global overuse to evidence based recommendations. Pancreatology 2019 ; 19: 488-499.

\section{„Invitum cum retineas, exire incites." (Publilius Syrus) (Távozásra biztatod azt, akit akarata ellenére visszatartasz.)}

A cikk a Creative Commons Attribution 4.0 International License (https://creativecommons.org/licenses/by/4.0/) feltételei szerint publikált Open Access közlemény melynek szellemében a cikk bármilyen médiumban szabadon felhasználható, megosztható és újraközölhető, feltéve, hogy az eredeti szerző és a közlés helye, illetve a CC License linkje és az esetlegesen végrehajtott módosítások feltüntetésre kerülnek. (SID_1) 